\begin{tabular}{|c|c|c|}
\hline & Int.J.Curr.Microbiol.App.Sci (2021) 10(12): 353-368 & \\
\hline & $\begin{array}{l}\text { International Journal of Current Microbiology and Applied Sciences } \\
\text { ISSN: 2319-7706 Volume } 10 \text { Number } \mathbf{1 2}(\mathbf{2 0 2 1 )} \\
\text { Journal homepage: } \underline{\text { http://www.ijcmas.com }}\end{array}$ & 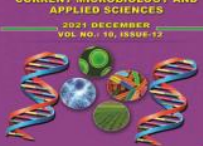 \\
\hline $\begin{array}{l}\text { EXCELLENT } \\
\text { PUBLISHERS }\end{array}$ & & \\
\hline
\end{tabular}

\title{
Physiological Constraints to Milk Production in High Yielding Dairy Cows
}

\author{
Ali-Gholi Ramin ${ }^{1}$, Gholamali Moghadam ${ }^{2}$, Siamak Asri-Rezaei ${ }^{1}$, Sharam Nozad ${ }^{1}$, \\ Sina Ramin ${ }^{3}$ and Clive J. C. Phillips ${ }^{4}$ \\ ${ }^{1}$ Department of Clinical Science, Faculty of Veterinary Medicine, Urmia University, Iran \\ ${ }^{2}$ The Agricultural College, Tabriz University, Iran \\ ${ }^{3}$ Medical college of Tabriz university, Tabriz, Iran \\ ${ }^{4}$ Centre for Animal Welfare and Ethics, School of Veterinary Science, University of \\ Queensland, Gatton 4343, QLD, Australia \\ *Corresponding author
}

\section{Keywords \\ blood, dairy cow, milk yield, \\ hematology, minerals}

\section{Article Info}

Received: 05 November 2021 Accepted: 02 December 2021 Available Online: 10 December 2021

\section{A B S T R A C T}

Milk yields and their relationships with blood and milk metabolic parameters were assessed in 59 high-yielding Holstein cows over the course of their lactation to identify metabolic constraints to daily milk production. Over an 11 month lactation period the cows, which were milked thrice daily and fed a total mix ration, had a mean daily milk yield of $35.5 \mathrm{l}$. Blood parameters monitored were haematocrit (PCV), erythrocytes (RBC), leucocytes (WCC), hemoglobin, neutrophils, lymphocytes, monocytes, eosinophils, urea, protein, creatinine, triglycerides, cholesterol, magnesium $(\mathrm{Mg})$, phosphorus $(\mathrm{P})$, calcium $(\mathrm{Ca})$, sodium $(\mathrm{Na})$, potassium $(\mathrm{K})$, chloride $(\mathrm{Cl})$, aspartates aminotransferase (AST), alanine aminotransferase (ALT), alkaline phosphatase (ALP), and glutamic gammatransferase (GGT). Stepwise regression indicated that blood haemoglobin concentration was most closely and positively correlated with milk yield, indicating that oxygen-carrying capacity was potentially a limit to milk production. Secondly, milk Na was negatively correlated with milk yield, and milk protein yield was negatively correlated with milk $\mathrm{Mg}, \mathrm{Ca}$ and $\mathrm{Na}$, demonstrating lack of homeostatic control of these elements in milk. Principal component analysis identified a primary metabonomic axis of hemoglobin and $\mathrm{RBC}$ concentrations at one end and blood $\mathrm{K}, \mathrm{Na}$ and milk lactose at the other, which appeared related to milk production. A second axis was apparent of milk divalent cations at one end and monovalent cations at the other. It is concluded that constraints to milk production in high yielding cows may exist due to limited oxygen-carrying capacity of the blood, as well as monovalent cations. 


\section{Introduction}

The bovine mammary gland yields considerably more milk and milk constituents than are required by a calf. As a result of the deficit of nutrient intake dairy cows are under metabolic stress for the early part of their lactation, and there has been considerable research in the evaluation of metabolic markers for such nutritional stress (Ollier et al., 2016). However, although the use of metabolic profiles is well established in humans, and methods have been widely researched and developed in dairy cows they have not entered widespread use in the dairy industry (Djoković et al., 2017). Their value is predicated on a relationship between metabolic constituents of blood or milk and the health and productivity of the dairy cows (Strzałkowska and Jóźwik 2021). In addition, the research on metabolic profiles has been almost universally conducted with low yielding dairy cows (Kumar and Pachhauri, 2000), whereas it is the high yielding cows that are increasingly used in intensive systems of production which are more likely to be challenged physiologically (Hasan et al., 2021). A new science of metabonomics (the quantitative measurement of the dynamic multiparametric metabolic response of living systems to pathophysiological stimuli or genetic modification, Nicholson, 2006, Sun et al., 2015) is emerging that may offer diagnostic capabilities to veterinarians using the metabolic profiles of high yielding cows (Donat et al., 2016).

The bovine mammary gland is capable of extracting nutrients from large volumes of blood, with more than 5001 processed to produce 11 of milk (Delamaire and GuinardFlament 2006). However, intake restrictions in early lactation and excessive nutrient demands render adipose tissue loss inevitable (Contreras et al., 2016). This places the cow at high risk of metabolic disorders, and it is therefore beneficial to understand the metabolism of high yielding Holstein dairy cows in relation to the correlations between milk yield, blood (Nozad et al., 2013) and milk components (Nozad et al., 2012). The risk of metabolic challenges is particularly high in the newly developing intensive dairies, such as in Azerbaijan in Iran, where the genetics of the dairy cows have been radically changed from native breeds (Hashemi et al., 2009) to Holstein Friesian cows (Ramin et al., 2005) over the last 40 years, mainly by importing pure breeds from Canada and Germany. In such situations, adequate feed quality and quantity are not always as well assured as in systems that have been operating in Western countries for several decades. The metabolic profile test can assist such developing dairy industries by better quantifying dairy metabolic parameters (Bashtani et al., 2009; Hossein-Zadeh et al., 2011) to prevent disease and improve milk yield, using key indices in blood, milk and feed (Sakhaee et al., 2011, Mokhber et al., 2011). The aims of this study were to investigate the relationships between milk yield and a variety of key milk and blood metabolic indicators to identify metabolic constraints to daily milk production in a newly developed intensive milk production system in Azerbaijan.

\section{Materials and Methods}

\section{Animals}

A commercial dairy herd of 1500 Holstein cows in Azerbaijan (mean daily temperature range $13-34^{\circ} \mathrm{C}$, altitude $1361 \mathrm{~m}$, mean annual humidity $58 \%$ and total rainfall $288 \mathrm{~mm}$ ) was used as the basis for the study of metabonomic parameters related to milk production. One hundred and forty-seven cows were considered to be high yielding (Dobson et al., 2007) and in good health and condition, which was determined by the absence of clinical 
disease symptoms and from blood analyses. From these 78 cows were randomly selected for the study, aged 5 to 6 years old and in their third or fourth parity, which entered the study over a three-month period. Fifty-nine of the selected cows remained throughout the study (due to selling, missing data, mastitis and emergency culling) within the main herd, which was split into three groups of high (up to 4 months), medium ( $5^{\text {th }}$ to $8^{\text {th }}$ month) and low yielding cows $\left(9^{\text {th }}\right.$ to $11^{\text {th }}$ month of lactation). Annual welfare management included vaccination, deworming, hoof trimming, CMT tests and sanitary control.

\section{Feed and feed Analysis}

Cows were fed three times per day, after milking, two different total mixed rations in October to February (TMR1) and March to September (TMR2) ad libitum (Table 1).

These were prepared in and fed from 1 ton feeders in feed bunks (EzeFeed, Australia) with free access for all cows in the group. Mean DM intakes were 26.2 and $24.7 \mathrm{~kg} / \mathrm{d}$, respectively. Feed subsamples of mean wet matter mass at least $50 \mathrm{~g}$ were taken monthly from February to December 2011 for chemical composition analysis. Crude protein content was measured by the Kjeldahl method and GE content by calculation of the carbohydrate (CHO), dry matter (DM), CP, ash, ether extract (EE) and crude fiber (CF) according to the following formula:

$\mathrm{CHO} \%=100-($ Moisture $\%+\mathrm{CP} \%+$ Ash $\%$ $+\mathrm{EE} \%+\mathrm{CF} \%$ )

$\mathrm{GE}(\mathrm{Cal} / 100 \mathrm{gm}$ diet $)=\mathrm{CP} \% \times 5.65+\mathrm{EE} \%$ x $9.40+\mathrm{CHO} \%$ x 4.15

Mean DM content of the diet was $582 \mathrm{~g} / \mathrm{kg}$ and mean concentrations in DM of $\mathrm{CF}$, ash, $\mathrm{CP}$, and $\mathrm{EE}$ were $20.4 \%, 5.5 \%, 34 \%$, and $2.39 \%$, respectively, over the 11 -month period
(Nozad et al., 2013). Ca and $\mathrm{P}$ concentrations were measured at 1 and $0.5 \%$ of feed DM, respectively.

\section{Blood sampling and analysis}

Blood samples were taken monthly from February to December 2011. Five ml of blood were extracted from each cow after morning milking starts from 8 am by jugular venipuncture monthly into a test tube without EDTA. Blood samples were separated by centrifuge at $3000 \mathrm{~g}$ for $5 \mathrm{~min}$ and stored at $20^{\circ} \mathrm{C}$ before analysis.

Two ml was mixed with EDTA and used for 9 hematological tests and the remaining $3 \mathrm{ml}$ was used after the separation of serum for 16 biochemical, mineral, and enzymatic tests.

PCV was determined by centrifuging blood in a microhaematocrit tube at $1500 \mathrm{~g}$. RBC and WCC were determined after dilution of the blood using a haemocytometer with Neubaurer grid, and hemoglobin (mg/dl) was measured by the cyanomethaemoglobin method. Leucocytes were differentiated into neutrophils, lymphocytes, monocytes and eosinophils by counting 200 leucocytes in each microscopic evaluation and converting \% into an absolute count.

Blood sera were also used to determine concentrations of urea, protein, creatinine, triglycerides, cholesterol, $\mathrm{Mg}, \mathrm{P}, \mathrm{Cl}, \mathrm{AST}$, ALT, ALP, and GGT using an auto analyzer (RA-1000, USA) and the appropriate commercial kits (Pars Azmoun, Iran).

Serum $\mathrm{Na}$ and $\mathrm{K}$ were measured by flame photometer using appropriate standards (Jenway, Clinical PFP7, UK). The concentration of $\beta$-hydroxybutyrate was determined by spectrophotometry (Ultra-violet method), using a Runbut kit (Randox Laboratories, Crumlin, UK). 


\section{Milk sampling and analysis}

Milk yield was measured daily and mean values presented that were weighted for the number of cows still lactating. Milk samples were taken monthly over the 11-month period, from February to December 2011. Cows were milked three times daily in a Westphalia parlor (GEA-Farm Technologies, Germany), and $10 \mathrm{ml}$ daily milk samples from each teat were taken from a morning milking of each cow monthly and refrigerated to $4^{\circ} \mathrm{C}$ until analysis. Milk serum was obtained by centrifugation at $3000 \mathrm{~g}$ for 5 minutes. Milk casein was separated by $0.1 \mathrm{~N} \mathrm{HCl}$ in $\mathrm{pH} 3.6$ (Nozad et al., 2013). Milk serum was used to determine the protein and macro-mineral concentrations. $\mathrm{Ca}, \mathrm{P}$ and $\mathrm{Mg}$ concentrations were measured using $\mathrm{Ca}, \mathrm{P}$ and $\mathrm{Mg}$ kits (Pars Azmoon Co., Tehran, Iran) in an autoanalyzer (RA-1000, Pharmacia Co., LKB, Novaspec, USA). Milk $\mathrm{Na}$ and $\mathrm{K}$ concentrations were assessed by flame photometer (Jenway PFP-7, Essex, UK) using a standard $\mathrm{Na}^{+}$and $\mathrm{K}^{+}$test (Ziest Chimi Diagnostics, Tehran, Iran). Milk lactose was assessed by Polarimeter (Bellingham and Stanley, UK). Milk urea was measured first by precipitation of total protein, separation of the milk serum and then was run as blood urea. Milk protein was determined in milk serum by using spectrophotometry commercial kits.

\section{Statistical analysis}

SPSS $_{13}$ and Minitab statistical programs were used for all analyses. ANOVA was used to determine the significance of monthly variation in mean concentrations of all parameters, with month as a factor in the model and cow as a random factor. Residuals were tested for normal distribution with results confirmed by Mood's median test where necessary. A forwards-backwards stepwise regression was conducted with the cows with entire datasets of milk yield and milk protein yield on 16 predictors with alpha values to enter and remove variables set at 0.10 .

\section{Results and Discussion}

Mean daily milk yield was $35.5 \mathrm{l} / \mathrm{d}$, and after an initial increase in the second month to a mean of $44.8 \mathrm{l} / \mathrm{d}$, it declined to $27.4 \mathrm{l} / \mathrm{d}$ at a rate of $0.068 \mathrm{l} / \mathrm{d}(0.16 \% / \mathrm{d})$ (Table 2, Fig1). The range in milk yields is presented in Table 2. The mean $\pm \mathrm{SE}$ monthly concentrations in blood of PCV, hemoglobin, RBC and WBC were $31 \% \pm 0.05,10.6 \pm 0.02 \mathrm{mg} / \mathrm{dl}, 5.3 \pm 0.005 \mathrm{x}$ $10^{6}$ cells $/ \mathrm{mm}^{3}$ and $8919 \pm 33.2$ cells $/ \mathrm{mm}^{3}$, respectively. Mean urea, protein, glucose, creatinine, cholesterol, triglycerides and $\beta$ hydroxybutyrate concentrations were $33.1 \pm 0.18,9.7 \pm 0.06,44.7 \pm 0.16,0.83 \pm 0.004$, $148.1 \pm 1.54,116.8 \pm 2.7 \mathrm{mg} / \mathrm{dl}$ and $0.61 \pm 0.004$ $\mathrm{mmol} / \mathrm{l}$. Mean $\mathrm{Ca}, \mathrm{P}, \mathrm{Mg}, \mathrm{Na}, \mathrm{K}$ and $\mathrm{Cl}$ concentrations were $9.42 \pm 0.03,5.36 \pm 0.09$, $2.97 \pm 0.02 \mathrm{mg} / \mathrm{dl}, 137.2 \pm 0.52,4.9 \pm 0.02$ and $103.2 \pm 0.13 \mathrm{mmol} / \mathrm{l}$ and AST, ALT, ALP and GGT concentrations were 109.1 \pm 0.67 , $116.7 \pm 0.10, \quad 31.4 \pm 1.45, \quad 19.2 \pm 0.08 \mathrm{mg} / \mathrm{dl}$, respectively.

All parameters differed significantly between months of lactation $(\mathrm{P}<0.05)$. Blood triglycerides increased rapidly after the first month, remained high for 5 months and then low for the remainder of the lactation period (Fig 2). Blood protein was low for the first 5 months, and then increased for the remainder of the lactation period (Fig 3). Blood urea $\mathrm{N}$ increased erratically for the first 7 months and then decreased (Fig 4). Blood P increased between months one and two, and then declined until month 6 , after which it was stable (Fig 5). Blood $\mathrm{Mg}$ and $\mathrm{Ca}$ both increased erratically throughout the lactation (Fig 6 and 7). Blood alkaline phosphatase increased between months one and two, and then declined (Fig 8). Blood hemoglobin declined erratically over the course of the lactation (Fig 9). 
A stepwise regression of milk yield for the cows with complete datasets for the 17 blood and milk parameters produced two significant correlations: first, a positive correlation with hemoglobin $(\mathrm{P}<0.001)$ and second, a negative correlation with milk Na $(\mathrm{P}=0.007)$ (Table 3). There was a trend for a positive correlation with milk $\mathrm{P}$ concentration $(\mathrm{P}=$ 0.06).

The regression equation for milk yield and hemoglobin was:

Milk yield $(\mathrm{kg} / \mathrm{d})=3.4+0.083$ hemoglobin, $\mathrm{s}$ $=6.79,(\mathrm{P}<0.001)$

The stepwise regression of milk protein yield with 17 blood and milk parameters produced six steps introducing significant variables: first the inclusion of milk $\mathrm{Mg}$, then milk $\mathrm{Ca}$, then blood $\mathrm{Na}$, all with negative coefficients, then milk $\mathrm{P}$ and WBC, both with positive coefficients (Table 4).

Principle component analysis (Table 5) produced two initial components for which the loading plot described the main clusters of responses (Fig 1). A cluster of variables in the top right-hand corner, with high responses in both components, included milk $\mathrm{K}, \mathrm{Na}, \mathrm{P}$, protein and urea, together with neutrophil concentrations in blood. At the opposite corner is milk $\mathrm{Ca}, \mathrm{Mg}$, and blood lymphocytes. Milk yield and blood $\mathrm{Cl}$ were centrally located, therefore unrelated to these two components. In the other diagonal, RBC, hemoglobin and PCV were opposite blood K, $\mathrm{Na}$ and milk lactose.

In this study, the mean daily milk yield was $35.5 \mathrm{l} / \mathrm{d}$, and in peak lactation $44.8 \mathrm{l} / \mathrm{d}$, with an individual maximum monthly yield of $67 \mathrm{l} / \mathrm{d}$, indicating a milk yield comparable with top dairy cow production in the world (Sun et al., 2015, Strzałkowska and Jóźwik 2021). By the definition of Dobson et al., (2007) for
Holstein cows, these cows were high yielding. The key variable to relate to milk yield was hemoglobin concentration in blood, which showed an erratic decline over the lactation and positive correlation with milk yield. Other authors have indicated a reduction in hemoglobin with increasing milk yield (Kumar and Pachauri, 2000), but this was probably confounded by season, milk yield level and other factors. They used crossbred cows, including heifers, many of which were low yielding and their study was conducted at an altitude of $1700 \mathrm{~m}$ in the central Himalayas (Kumar and Pachauri 2000). As milk yields have increased over the last 50 years, hemoglobin concentrations in dairy cows have declined (George et al., 2010), again suggesting an antagonistic relationship. Another study observed a reduction in hemoglobin concentration over the early part of lactation in dairy cows. The antagonistic relationship between hemoglobin status and milk yield in our study may differ from previous ones because our high yielding cows had considerably greater metabolic needs. Sustaining such high milk yields would have had a high metabolic requirement for feed digestion, nutrient processing and milk production (Djoković et al., 2017, Hong 2019). All this requires large amounts of energy, and it is therefore evident that oxygen requirement is one of the main drivers of hemoglobin status (Abd Ellah 2016). In support of this, alpine cows increase hemoglobin concentration to cope with high altitude (Berry et al., 2001), and ewes increase hemoglobin concentration in response to walking stress (Seijan et al., 2012). Oxygen requirements for metabolism in the dairy cow are considerable and are increased by high milk yields (Sordillo 2005). Because of this, it is not surprising that hypoxia is one factor reducing productivity at high altitudes, at least before adaptation (Leiber et al., 2004). In the early lactation cow, nutrient demands exceed the provision from intake, and mobilization of 
body tissues is essential to sustain high production. The visceral hypertrophy in response to these demands, in particular the splanchnic tissues and increased hepatic artery flow, facilitate increased oxygen supply to the liver (Reynolds et al., 2003). By 12 weeks' postpartum oxygen consumption by the splanchnic tissues has increased by more than blood flow, which may be due to increased hemoglobin concentrations in high yielding cows.

Many other factors affect hemoglobin status and these must be verified; for example, the hemoglobin status of dairy cow's cattle can also be reduced if $\mathrm{Fe}$ or $\mathrm{Cu}$ status is low (Yang et al., 2007). Hemoglobin status is also increased by heat stress (Timisoar et al., 2018), and hot temperatures can increase hemoglobin in blood in Holstein-Friesian cows, probably due to enhanced respiration rates (Sammad et al., 2020). The temperature experienced in this experiment ranged from 13 to $34^{\circ} \mathrm{C}$, but hot temperatures did not coincide with high hemoglobin status of the cows, which was highest in the early part of lactation in March.

It is possible that any positive correlation between milk yield and hemoglobin is not causal. Khaled et al., (1999) observed that hemoglobin was negatively correlated with milk fat content in dairy goats, which could produce a positive correlation with milk yield. Near infrared spectroscopy offers the potential for non-invasive measurements of hemoglobin that can distinguish between oxyhemoglobin and deoxyhemaglobin (Oya et al., 2003), and this could be used to examine oxygen carrying capacity of hemoglobin in future studies.

There was evidence of antagonistic relationships between milk lactose, one of the primary milk osmolytes, together with associated monovalent cations in blood, and the RBC, hemoglobin, PCV complex, although the latter is confounded with other constituents. Milk lactose concentration declines in late lactation, especially if cows are underfed, and demonstrates an antagonistic relationship with milk yield (Phillips, 2010). $\mathrm{Na}$ and $\mathrm{K}$ often change antagonistically in the mammary gland, the former increasing in response to damage to the epithelial tissue during mastitis, which allows the Na to diffuse into the mammary gland, however, our loading plot indicated a close relationship between variation in $\mathrm{Na}$ and $\mathrm{K}$ in blood and milk lactose. These are related to the osmotic pressure of blood and have been observed previously (Bijl et al., 2013).

The second axis to emerge from the PCA was one apparently related in part to the valence of milk cations. Also active at this end of the axis was the neutrophil concentration, which is the central reaction to invasion of the gland by bacteria. This indicates that responses to subclinical or clinical mastitis were driving this end of the axis. Lymphocytes are usually depleted in mastitic milk, at the same time as neutrophils increase in number (Hussain et al., 2012), and their proliferation is dependent on $\mathrm{Ca}$, which is often deficient at this time (Kimura et al., 2006). Divalent cations, however, are neither osmotically active nor homeostatically controlled in milk, yet they are potentially deficient in their support for the lymphocyte response to bacterial infection of the mammary gland. $\mathrm{Ca}$ and $\mathrm{Mg}$ absorption are inextricably linked in ruminants (Chiy and Phillips, 1993), and it is therefore plausible that $\mathrm{Mg}$ would play an equivalent role to $\mathrm{Ca}$ in supporting lymphocyte proliferation.

Milk protein yield indicated a negative regression with milk $\mathrm{Mg}, \mathrm{Ca}$ and $\mathrm{Na}$ concentration, and milk yield similarly had a negative correlation with milk $\mathrm{Na}$ concentration (Salim and Salman 2020). 
Table.1 Feed ingredients, diet composition and DM intake (\% unless otherwise specified) for October to February (TMR1) and March to September (TMR2) diets in dairy cows

\begin{tabular}{|c|c|c|}
\hline Ingredients & $\begin{array}{c}\text { TMR 1 } \\
\text { October to February }\end{array}$ & $\begin{array}{c}\text { TMR2 } \\
\text { March to September }\end{array}$ \\
\hline Alfalfa hay (chopped) & 20.8 & 20.5 \\
\hline Corn Silage & 16.31 & 14.7 \\
\hline Dry Apple Pulp & 3.45 & 5.1 \\
\hline Wet cane molasses & 2.13 & 1.58 \\
\hline Meat Meal & 1.83 & 1.72 \\
\hline Whole barley grains & 9.77 & 15.86 \\
\hline Cottonseed meal & 2.65 & 2.68 \\
\hline Cottonseed lint & 6.33 & 6.43 \\
\hline Corn Stover & 16.51 & 11.07 \\
\hline Wheat straw (chopped) & 1.81 & 1.88 \\
\hline Calcium carbonate $\left(\mathrm{CaCO}_{3}\right)$ & 0.70 & 0.70 \\
\hline Salt $(\mathrm{NaCl})$ & 0.31 & 0.28 \\
\hline Sodium bicarbonate $\left(\mathrm{NaHCO}_{3}\right)$ & 0.94 & 0.93 \\
\hline Fishmeal & 1.07 & 1.07 \\
\hline Tallow & 1.56 & 1.54 \\
\hline Soya meal & 7.31 & 7.41 \\
\hline Vitamins & 1.95 & 1.91 \\
\hline Canola meal & 3.53 & 3.66 \\
\hline $\begin{array}{l}\text { Wheat bran } \\
{ }^{1} \text { Composition }\end{array}$ & 1.04 & 1.08 \\
\hline Net energy (MJ/kg) & 6.78 & 6.78 \\
\hline Crude protein & 17.1 & 17.4 \\
\hline NDF & 29.1 & 29.9 \\
\hline ADF & 19.0 & 19.2 \\
\hline $\mathbf{C a}^{\dagger}$ & 1.0 & 1.0 \\
\hline $\mathbf{P}^{\dagger}$ & 0.5 & 0.5 \\
\hline DM intake, kg/d & 26.6 & 24.7 \\
\hline
\end{tabular}

${ }^{\dagger}$ Mean measured values, ${ }^{1}=$ Assessed based on standard units with current laboratory methods (Nozad et al., 2013). 
Table.2 Weighted least square means, SEM and range of milk yields in Holstein dairy cows over the 11 months of lactation in high, moderate and low milk yielding group

\begin{tabular}{|c|c|c|}
\hline Months of lactation & Mean \pm SE $(1 / d)$ & Range (1/d) \\
\hline \multicolumn{3}{|c|}{ High milk yielding group } \\
\hline 1 & $50.6 \pm 0.59$ & $46.0-65.0$ \\
\hline 2 & $43.2 \pm 0.17$ & $41.0-45.6$ \\
\hline 3 & $42.8 \pm 0.32$ & $41.6-45.6$ \\
\hline 4 & $40.8 \pm 0.50$ & $40.6-41.0$ \\
\hline \multicolumn{3}{|c|}{ Moderate milk yielding group } \\
\hline 5 & $39.2 \pm 0.11$ & $38.0-40.4$ \\
\hline 6 & $36.7 \pm 0.11$ & $35.0-38.0$ \\
\hline 7 & $33.6 \pm 0.13$ & $32.0-35.0$ \\
\hline 8 & $30.1 \pm 0.14$ & $28.0-32.0$ \\
\hline \multicolumn{3}{|c|}{ Low milk yielding group } \\
\hline 9 & $25.5 \pm 0.20$ & $23.2-28.0$ \\
\hline 10 & $19.4 \pm 0.32$ & $16.6-23.0$ \\
\hline 11 & $11.4 \pm 0.58$ & $3.5-16.5$ \\
\hline Mean & $35.5 \pm 0.06$ & $3.5-65.0$ \\
\hline
\end{tabular}

Table.3 Regression coefficients, $\mathrm{T}$ and $\mathrm{P}$ values for a stepwise regression of mean milk yields of 59 cows on 17 blood and milk parameters

\begin{tabular}{lccc} 
Step & 1 & 2 & 3 \\
\hline haemoglobin & 3.4 & 6.1 & 5.3 \\
T-Value & 40.1 & 4.4 & 3.8 \\
P-Value & 0.000 & 0.000 & 0.000 \\
& & & \\
Milk Na & & -1.36 & -2.69 \\
T-value & & -1.98 & -2.78 \\
P-value & 0.05 & 0.007 \\
Milk P & & \\
T-Value & & & 2.4 \\
P-Value & & 1.91 \\
\hline
\end{tabular}


Table.4 Regression coefficients, $\mathrm{T}$ and $\mathrm{P}$ values for a stepwise regression of mean milk protein yields of 59 cows on 17 serum and milk parameters

\begin{tabular}{lcccccc} 
Step & 1 & 2 & 3 & 4 & 5 & 6 \\
\hline Constant & 58.6 & 123.2 & 194.8 & 166.6 & 164.1 & 155.5 \\
Milk Mg & -14.4 & -12.0 & -9.0 & -5.7 & & \\
T-value & -3.11 & -2.65 & -1.99 & -1.22 & & \\
P-value & 0.003 & 0.01 & 0.05 & 0.23 & & \\
& & & & & & \\
Milk Ca & & -3.9 & -4.6 & -4.1 & -4.4 & -5.0 \\
T-value & -2.51 & -3.01 & -2.73 & -2.98 & -3.34 \\
P-value & 0.01 & 0.004 & 0.009 & 0.004 & 0.002 \\
& & & -0.49 & -0.57 & -0.65 & -0.66 \\
Blood Na & & -2.43 & -2.86 & -3.40 & -3.54 \\
T-value & & 0.02 & 0.006 & 0.001 & 0.001 \\
P-value & & & & & \\
& & & & 2.37 & 1.63 & 1.51 \\
Milk P & & & 0.04 & 2.69 & 2.54 \\
T-value & & & & 0.009 & 0.01 \\
P-value & & & & & 0.0025 \\
WBC & & & & & & 1.81 \\
T-value & & & & & & 0.076 \\
P-value & & & & & & \\
\hline
\end{tabular}

Table.5 Principle component analysis of 18 serum and milk parameters in Holstein dairy cows $(n=59)$

\begin{tabular}{|c|c|c|c|c|c|c|}
\hline Variable & PC1 & $\mathrm{PC}_{2}$ & $\mathrm{PC}_{3}$ & $\mathrm{PC} 4$ & PC5 & PC6 \\
\hline \multicolumn{7}{|l|}{ Blood } \\
\hline $\mathrm{Na}$ & -0.093 & 0.115 & -0.497 & 0.125 & -0.267 & 0.349 \\
\hline $\mathrm{K}$ & -0.198 & 0.189 & -0.412 & 0.028 & -0.325 & -0.046 \\
\hline $\mathrm{Cl}$ & -0.083 & -0.138 & -0.348 & 0.148 & 0.286 & -0.287 \\
\hline PCV & 0.306 & -0.437 & -0.100 & 0.006 & -0.067 & 0.074 \\
\hline Haemoglobin & n 0.278 & -0.441 & -0.091 & -0.004 & -0.114 & 0.051 \\
\hline $\mathrm{RBC}$ & 0.265 & -0.428 & -0.085 & -0.101 & -0.044 & 0.050 \\
\hline WBC & 0.057 & -0.104 & -0.248 & 0.204 & 0.020 & -0.423 \\
\hline Neutrophil & 0.284 & 0.208 & 0.167 & 0.401 & -0.283 & -0.106 \\
\hline Lymphocyte & -0.232 & -0.177 & -0.165 & -0.532 & 0.211 & 0.150 \\
\hline \multicolumn{7}{|l|}{ Milk } \\
\hline Urea & 0.173 & 0.254 & -0.182 & -0.262 & 0.257 & -0.090 \\
\hline Lactose & -0.098 & 0.155 & 0.110 & -0.420 & -0.367 & -0.127 \\
\hline Protein & 0.347 & 0.160 & 0.279 & -0.017 & 0.162 & -0.003 \\
\hline $\mathrm{Ca}$ & -0.214 & -0.017 & -0.080 & 0.225 & 0.327 & -0.357 \\
\hline $\mathbf{P}$ & 0.332 & 0.260 & -0.258 & -0.116 & 0.008 & -0.003 \\
\hline $\mathrm{Mg}$ & -0.226 & -0.081 & -0.048 & 0.375 & 0.115 & 0.454 \\
\hline $\mathrm{Na}$ & 0.333 & 0.184 & -0.205 & 0.043 & 0.047 & 0.267 \\
\hline $\mathrm{K}$ & 0.296 & 0.184 & -0.272 & -0.094 & 0.185 & -0.099 \\
\hline Yield & -0.027 & -0.147 & -0.075 & -0.071 & -0.461 & -0.363 \\
\hline Eigenvalue & 4.0 & 2.8 & 2.0 & 1.7 & 1.5 & 1.3 \\
\hline Proportion & 0.22 & 0.16 & 0.11 & 0.09 & 0.08 & 0.07 \\
\hline $\mathrm{S}$ & 4.77 & 4.56 & 4.37 & 4.23 & 4.25 & 4.17 \\
\hline R-Sq & 14.5 & 23.1 & 30.6 & 36.1 & 34.3 & 38.1 \\
\hline
\end{tabular}


Fig.1 Mean milk yield of dairy cows $(n=59)$ over 11 months of lactation

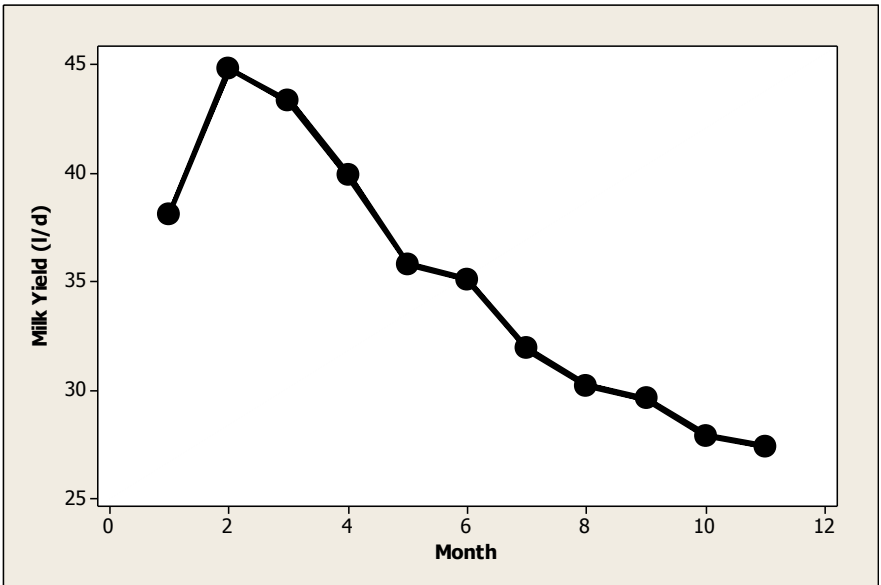

Fig.2 Mean serum triglyceride concentrations of dairy cows ( $=59)$ over 11 months of lactation

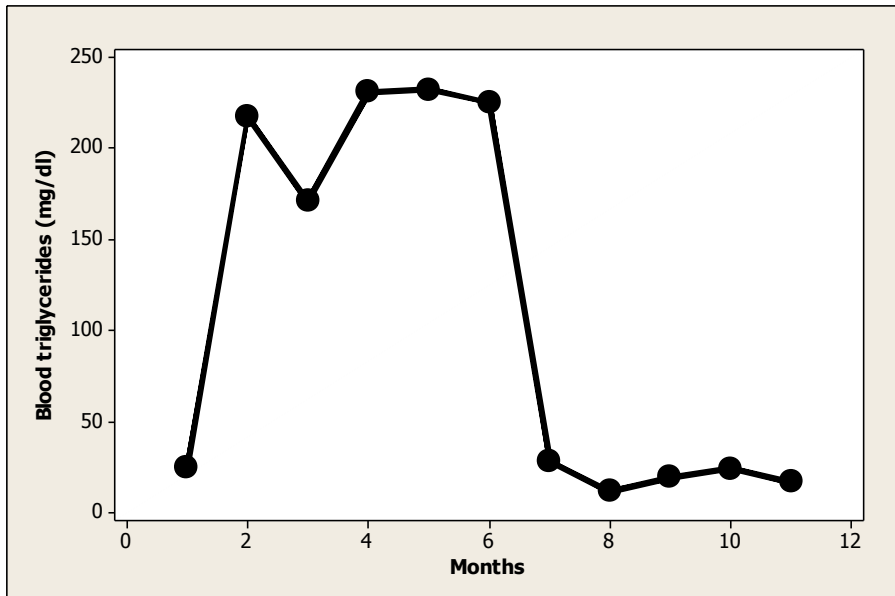

Fig.3 Mean serum protein concentrations of dairy cows $(n=59)$ over 11 months of lactation

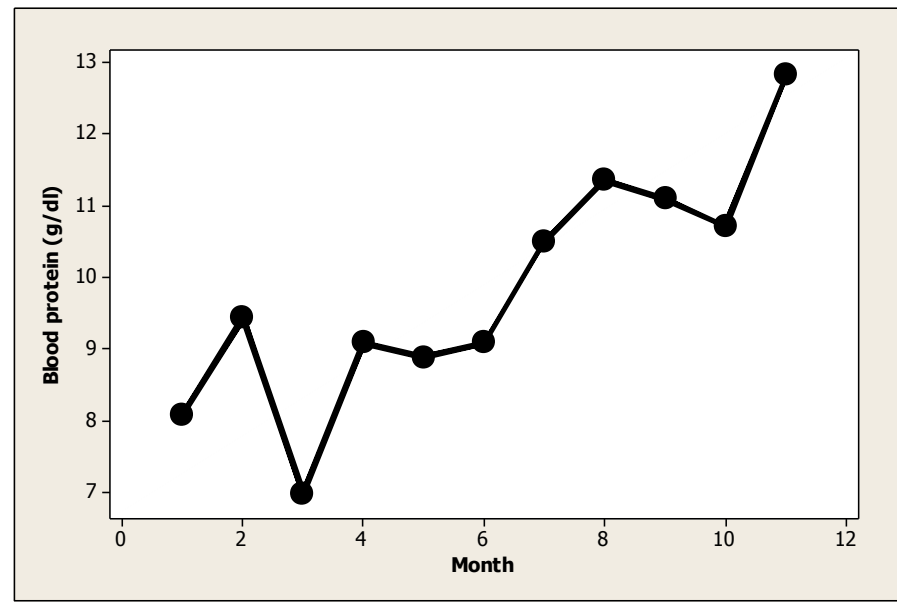


Fig.4 Mean serum urea nitrogen concentrations of dairy cows $(n=59)$ over 11 months of lactation

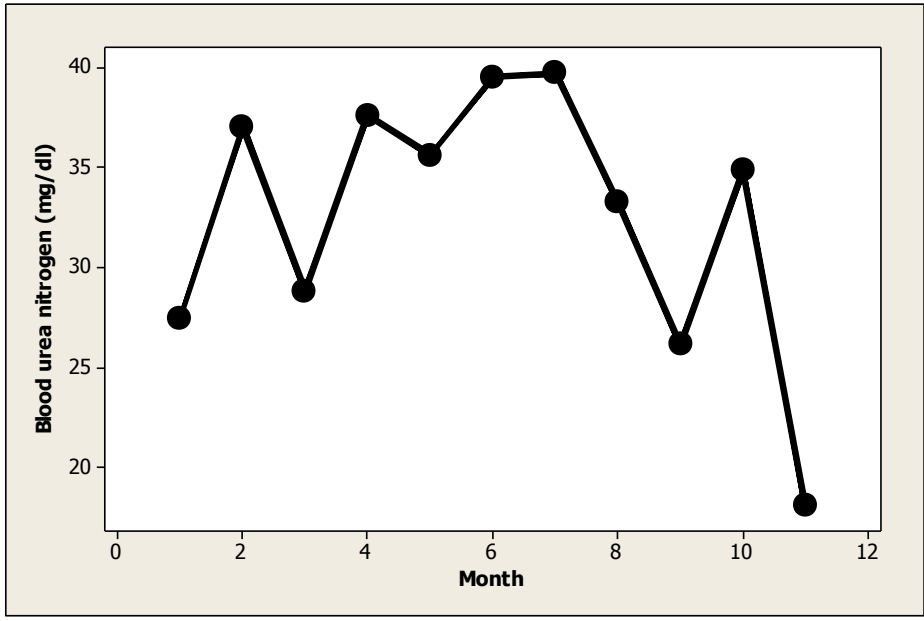

Fig.5 Mean serum P concentrations of dairy cows ( $\mathrm{n}=59)$ over 11 months of lactation

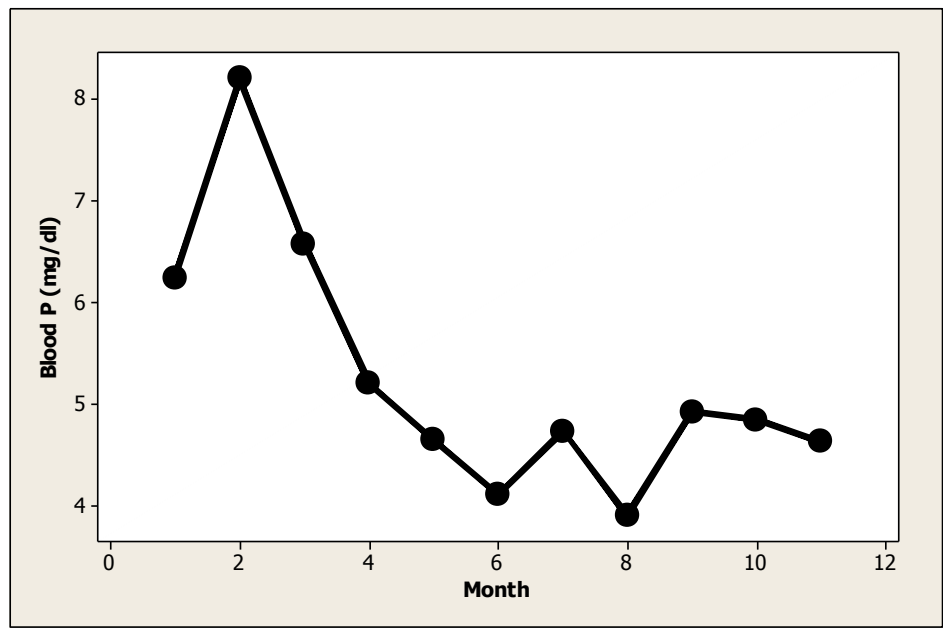

Fig.6 Mean serum Mg concentrations of dairy cows (n=59) over 11 months of lactation

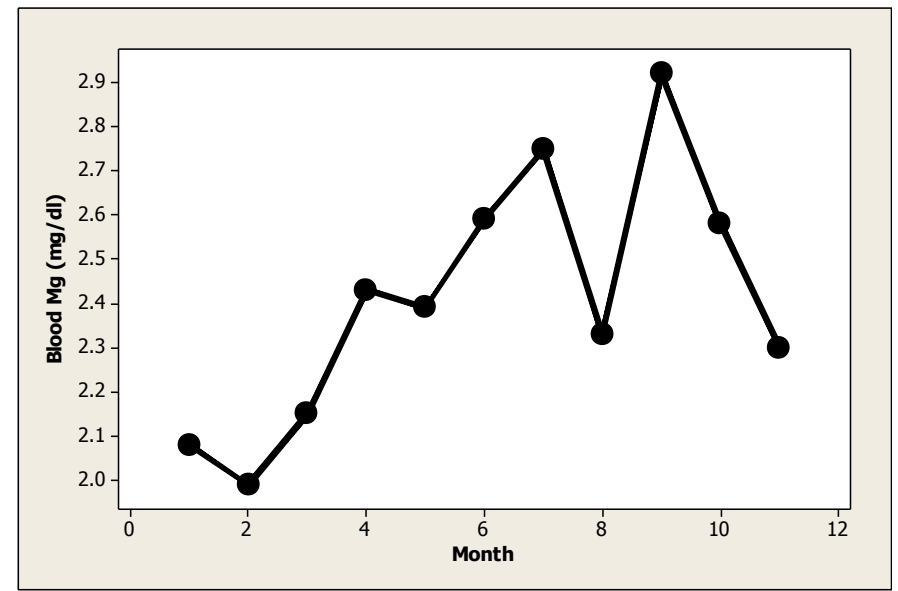


Fig.7 Mean milk Ca concentrations of dairy cows $(n=59)$ over 11 months of lactation

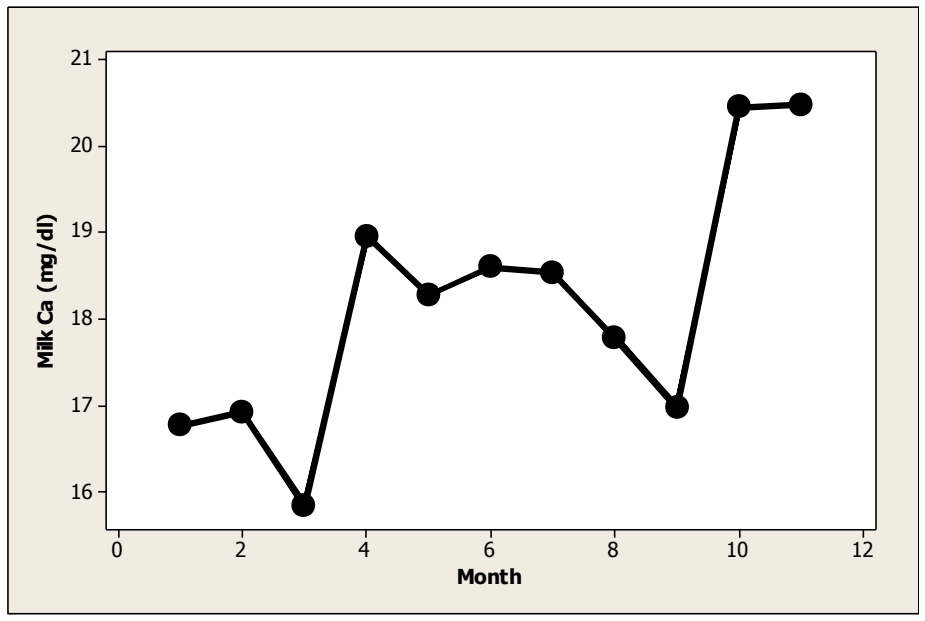

Fig.8 Mean serum alkaline phosphatase of dairy cows (n=59) over 11 months of lactation

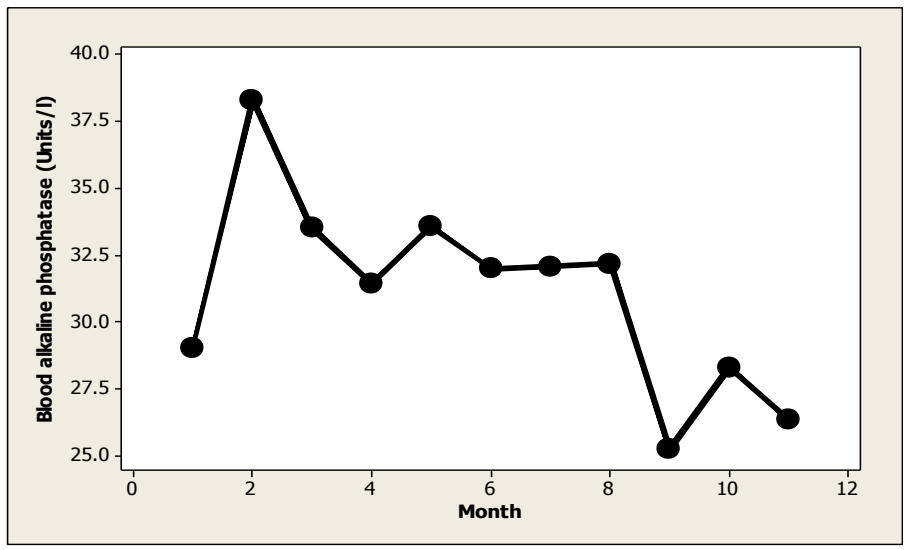

Fig.9 Mean serum haemoglobin concentrations of dairy cows $(n=59)$ over 11 months of lactation

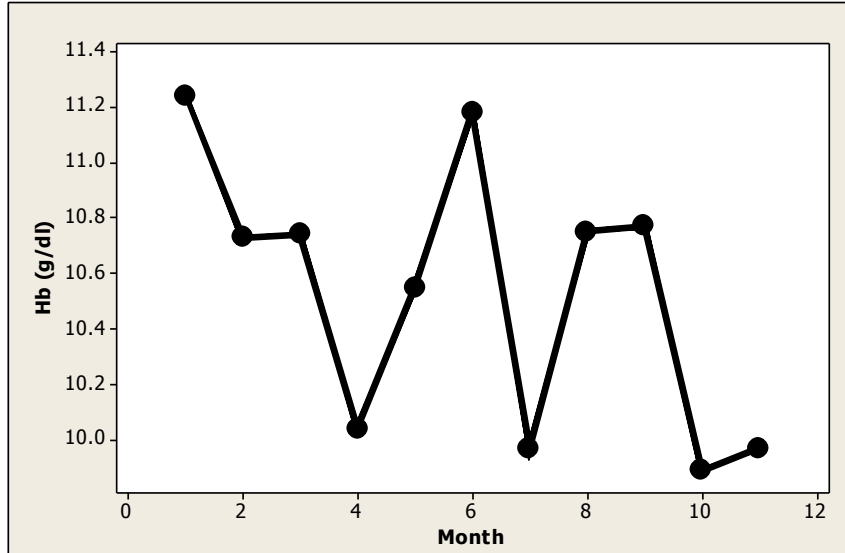


Fig.10 Loading plot of principal component analysis of the relationships between 18 serum and milk parameters

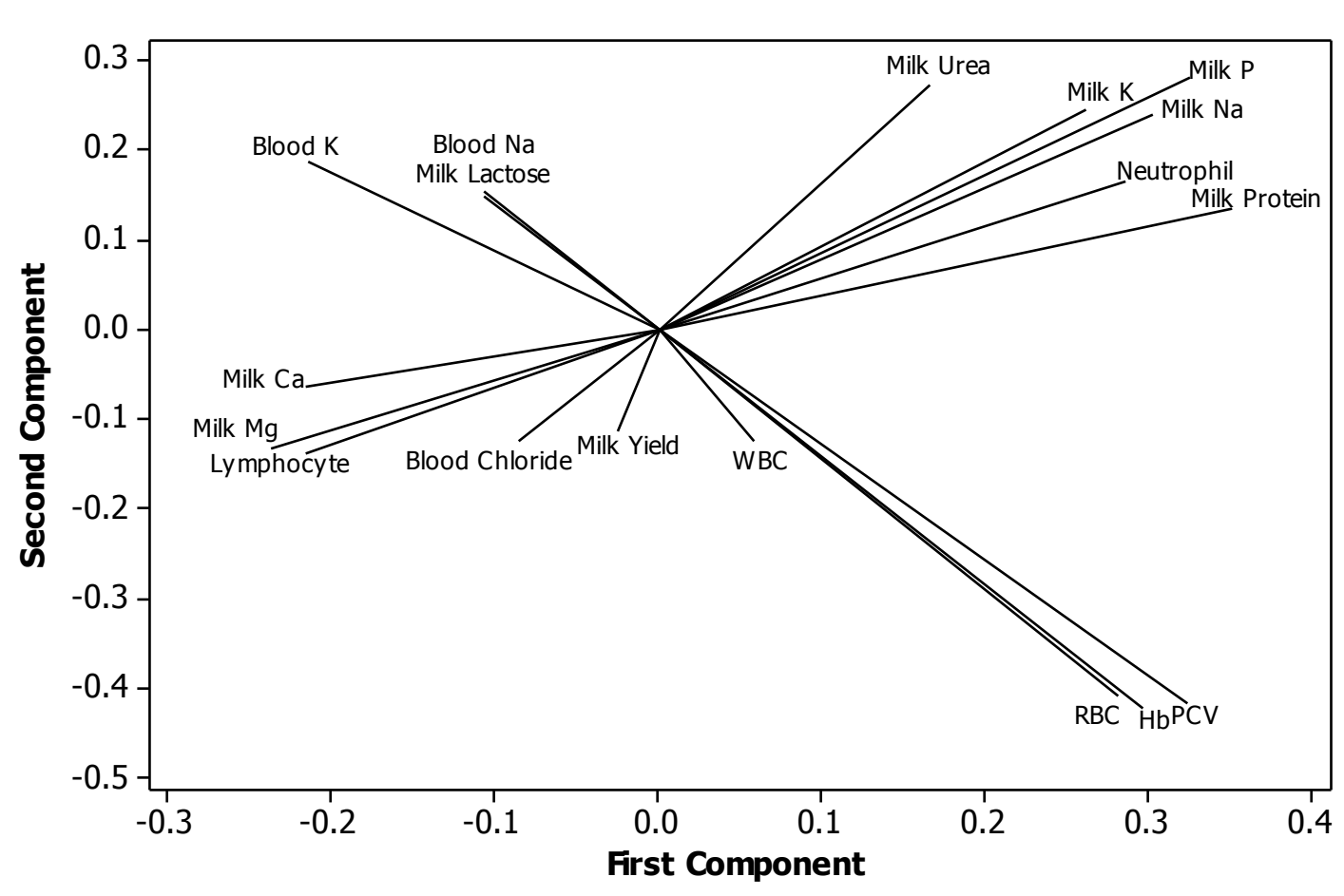

This is probably due to the reduction in the concentration of elements that are not homeostatically regulated as milk yield increases, rather than the protein concentration, because $70 \%$ of $\mathrm{Ca}$ and $30 \%$ of $\mathrm{Mg}$ are dispersed in colloidal calcium phosphate nanoclusters bound to caseins, with the remainder as free ions in milk serum (Bijl et al., 2013). Therefore, $\mathrm{Ca}$ and protein concentrations in milk are positively correlated, and $\mathrm{Mg}$ is also correlated with $\mathrm{Ca}$ (Bijl et al., 2013, Mordak et al., 2021). Metabolic profiles can help to identify constraints to milk production in high yielding industrial dairies. Our study found that a key metabolite in the conditions under which our high yielding cows were kept is hemoglobin, suggesting that hypoxia may limit nutrient utilization. This is the first time that hemoglobin has been detected as a possible constraint to milk production. Two major axes of metabolites were identified, one related to milk yield, with hemoglobin and RBC at one extreme and blood monovalent cations and milk lactose, all potentially involved in regulating milk yield. The second axis focused on responses to invasive bacteria, with neutrophils and the milk monovalent cations principally involved in mastitis responses at one end and the milk divalent cations and lymphocytes at the other.

\section{Acknowledgement}

The authors thank the Faculty of Veterinary Medicine (Urmia University, Urmia, Iran) for financial support for this study.

\section{References}

Abd Ellah M R, 2016. Oxidant and Antioxidants During the Transition Period in Dairy Cows. Journal of Advanced Veterinary Research, 6(4): 
130-133.

Bashtani M, Farhangfar H Naeimipour H \& Asghari M R 2009 Application of milk urea nitrogen index (MUN I) for monitoring protein nutrition status in lactating dairy cow. Journal of Agricultural Science and Natural Resources 16, 110-118.

Berry N R, Sutter F, Bruckmaier R M, Blum J W, Kreuzer M (2001) Limitations of high Alpine grazing conditions for early-lactation cows effects of energy and protein supplementation. Animal Science 73, 149-162.

Bijl E, van Valenberg, H J F, Huppertz T, van Hooijdonk ACM (2013) Protein, casein \& micellar salts in milk Current content and historical perspectives. Journal of Dairy Science 96, 54555464.

Chiy P C, Phillips C J C (1993) Sodium fertilizer application to pasture 4 Effects on mineral uptake and the sodium and potassium status of steers. Grass and Forage Science 48, 260-270.

Contreras G A, Thelen K, Schmidt S E, Strieder-Barboza C, Preseault C, Raphael W, Kiupel M, Caron J, Lock A L, 2016. Adipose tissue remodeling in late-lactation dairy cows during feed-restriction-induced negative energy balance. Journal of Dairy Science, 99, 12: 10009-10021

Delamaire E, Guinard-Flament J, 2006. Increasing Milking Intervals Decreases the Mammary Blood Flow and Mammary Uptake of Nutrients in Dairy Cows. Journal of Dairy Science, 89, 9: 3439-3446

Djoković R, Kurćubić1 V, Ilić Z, Cincović M, Lalović M, Jašović B, Bojkovski J, 2017. Correlation between blood biochemical metabolites milk yield, dry matter intake and energy balance in dairy cows during early and mid lactation. Advances in Diabetes and
Metabolism 5(2): 26-30.

Dobson H, Smith R F, Royal M D, Knight C H, Sheldon I M (2007) The high producing dairy cow and its reproductive performance. Reproduction in Domestic Animals 42, 17-23.

Donat K, Siebert, W, Menzer E, Söllner-Donat S, 2016. Long-term trends in the metabolic profile test results in German Holstein dairy herds in Thuringia, Germany. Tierarztl Prax Ausg G Grosstiere Nutztiere 44(02): 73-82

George J W, Snipes L, Lane V N (2010) Comparison of bovine hematology reference intervals from 1957 to 2006. Veterinary Clinical Pathology 39, 138148.

Hasan S, Islam K, Rahman M, 2021. Physiological Comparison of Some Serum Biochemistry between Lactating and Non-Lactating Dairy Cows in Selected Dairy Farms of Dhaka District of Bangladesh. ijcsrr.org Page No.- 53-58 53

Hashemi A, Bernousi I, Razzagh Zadeh S, Ranjbari M (2009) Estimates of Genetic Parameters of Productive Traits in Holstein-Native Crossbreds in W Azerbaijan Province. Iran Journal of Animal Veterinary Advances 8, 917919.

Hong H, Lee I F, Lee I H, Lee S R, 2019. Effects of transport stress on physiological responses and milk production in lactating dairy cows. Asian-Australas J Anim Sci. 32(3): 442-451.

Hossein-Zadeh N G, Ardalan M (2011) Estimation of genetic parameters for milk urea nitrogen and its relationship with milk constituents in Iranian Holsteins. Livestock Science 135, 274281.

Hussain R, Javed M T Khan A (2012) 
Changes in some biochemical parameters and somatic cell counts in the milk of buffalo and cattle suffering from mastitis. Pakistan Veterinary Journal 32, 418-421.

Khaled N F, Illek J, Gajdusek S (1999) Interactions between nutrition, blood metabolic profile and milk composition in dairy goats. Acta Veterinaria Brno 68, 253-258.

Kimura K, Reinhardt T A, Goff G P (2006) Parturition and hypocalcaemia blunts calcium signals in immune cells of dairy cattle. Journal of Dairy Science 89, 2588-2595.

Kumar B, Pachauri S P (2000) Haematological profile of crossbred dairy cattle to monitor herd health status at medium elevation in Central Himalayas. Research Veterinary Science 69, 141-145.

Leiber F, Kreuzer M, Jorg B (2004) Contribution of altitude and Alpine origin of forage to the influence of Alpine sojourn of cows on intake, nitrogen conversion, metabolic stress and milk synthesis. Animal Science 78, 451-466.

Mokhber M, Eftekhari Z, Sadeghian S, Bahounar A, Jeloudari M (2013) Evaluation of hematological and biochemical profiles in dairy cows with left displacement of the abomasums. Comparative Clinical Pathology 22, 175-179.

Mordak R, Dobrzański Z, Kupczyński R, 2021. Relationships among macrominerals, other selected serum markers of bone profile and milk components of dairy cows during late lactation. Ann. Anim. Sci., 21, 3: 887-898.

Nicholson J K (2006) Global systems biology, personalized medicine and molecular epidemiology. Molecular Systems Biology 2, 52-55.

Nozad S, Ramin A G, Asri-Rezaie S (2012)
Diurnal variations in milk macromineral concentrations in Holstein dairy cows in Urmia. Iran Veterinary Research Forum 3, 281-285.

Nozad S, Ramin A G Moghaddam Gh, AsriRezaie S, Kalantary L, Babapour A, Ramin S, Phillips CJC (2013) Monthly and seasonal evaluation of dietary nutrients and their relationships with blood and milk parameters in lactating dairy cows. Acta Veterinaria (Beograd) 63, 255-268.

Ollier S, Beaudoin F, Vanacker N, Lacasse P, 2016. Effect of reducing milk production using a prolactin-release inhibitor or a glucocorticoid on metabolism and immune functions in cows subjected to acute nutritional stress. Journal of Dairy Science, 99, 12: 9949-9961

Oya S, Inoue H, Nakade T (2003) Nearinfrared spectroscopy evaluated as a technique for estimating udder haemodynamic in the lactating cow. Journal of Veterinary Medicine Series A, Physiology, Pathology and Clinical Medicine 50, 230-234.

Phillips CJC (2010) Principles of Cattle Production, $2^{\text {nd }}$ Edn, pp 175, Wallingford: CABI

Ramin A G, Asri S, Salamat J (2005) Monthly and seasonal variation in milk plasma magnesium concentration in Friesian dairy herds in Urmia. Iranian Journal of Veterinary Research 6, 69-73.

Reynolds C K, Aikman P C, Lupoli B (2003) Splanchnic metabolism of dairy cows during the transition from late gestation through early lactation. Journal of Dairy Science 86, 12011217.

Salim A H, Salman R S, 2020. Analysis in Milk Compositions among Cattle, Sheep and Goats in Iraq: A Comparative Study. Indian Journal of Ecology, 47, (10): 84-85. 
Sakhaee E, Kheirandish R, Jafari H, Yaghoubi M A (2011) Fatty liver syndrome in dairy herds in southeast Iran. Comparative Clinical Pathology 20, 75-78.

Sammad A, Wang Y J, Umer S, Lirong H, Khan I, 2020. Nutritional physiology and biochemistry of dairy cattle under the influence of heat stress: Consequences and opportunities. Animals, 10(5): 793-798.

Sejian V, Maurya V P, Naqvi S M (2012). Effect of walking stress on growth, physiological adaptability and endocrine responses in Malpura ewes in a semi-arid tropical environment. International Journal of Biometerology $56,243-252$.

Sordillo L M (2005) Factors affecting mammary gland immunity and mastitis susceptibility. Livestock Production Science 98, 89-99.
Strzałkowska N, Jóźwik A, 2012. Relationship between milk yield, stage of lactation, and some blood serum metabolic parameters of dairy cows. Journal of Animal Science 57(8):353-360

Sun H Z, Wang D M, Wang B, Wang J K, Liu H Y, Guan L L, Liu J X, 2015. Metabolomics of four biofluids from dairy cows: potential biomarkers for milk production and quality. J. Proteome Res. 14 (2): 1287-1298.

Timisoar A, Morrar D, Ciulan V, Simiz F, Mot T, Hutu I, Vaduva C. 2018. Effect of hear stress on hematological parameters in dairy. Medicina Veterinaria,2: 65-70

Yang Z, Yang B and Jiang V R (2007) Effect of copper and zinc on blood and milk parameters and performance of dairy cows. Journal of Animal Feed Science $16,571-575$.

\section{How to cite this article:}

Ali-Gholi Ramin, Gholamali Moghadam, Siamak Asri-Rezaei, Sharam Nozad, Sina Ramin and Clive J. C. Phillips. 2021. Physiological Constraints to Milk Production in High Yielding Dairy Cows. Int.J.Curr.Microbiol.App.Sci. 10(12): 353-368. doi: https://doi.org/10.20546/ijcmas.2021.1012.041 